\title{
KETIDAKSEIMBANGAN INSTRUMEN PENILAIAN PADA DOMAIN PEMBELAJARAN
}

\author{
Yuberti \\ Program Studi Pendidikan Fisika FTK, IAIN Raden Intan Lampung; E-mail: yuberti_iain@yahoo.co.id
}

\begin{abstract}
Generally, the result of teaching and learning process pointed to three basic aspects, they are; cognitive, affective, and psycomotoric that must be achieved by the students. These three aspects can not be divided because they are a unity. Teaching and learning hold one important aspect in education, that is to develop and empower cognitive, affective, and psycomotoric to create students effectively. The three domains should be underwritten in teaching learning process they cover lesson planning, lesson implementation, the result of evaluation and supervision of teaching and learning process. Based on the concept result teaching and learning throughly, the teacher are obligated to make instruments for three domains in teaching and learning process and it's application. Various kind of evaluation are made to get the responsibly result of students' teaching and learning can describe students ability comprehensively.
\end{abstract}

Abstrak: Secara umum, hasil pembelajaran mengarah pada tiga hal pokok yang harus mampu dicapai peserta didik, yaitu Afektif, Kognitif dan Psikomotorik. Ketiga hal ini tidak boleh dipisahkan karena merupakan satu kesatuan. Pembelajaran sebagai salah satu aspek penting dalam pendidikan memegang peranan mengembangkan dan memberdayakan domain kognitif, afektif, dan psikomotor bagi peserta didik secara seimbang. Keseimbangan pengembangan dan pemberdayaan ketiga domain tersebut harus tertuang dengan jelas dalam proses pembelajaran, meliputi perencanaan pembelajaran, pelaksanaan pembelajaran, penilaian hasil pembelajaran, dan pengawasan proses pembelajaran. Berdasarkan konsep hasil belajar yang bersifat menyeluruh, sudah menjadi keharusan bahwa guru harus membuat instrumen pada ketiga ranah dalam pembelajaran tersebut dan melakukan penerapan penilaiannya. Berbagai bentuk penilaian dibuat untuk memperoleh hasil belajar peserta didik yang dapat dipertanggungjawabkan serta benar-benar dapat menggambarkan kemampuan peserta didik secara komprehensif.

Kata kunci: domain pembelajaran, instrumen penilaian, ketidakseimbangan, 


\section{PENDAHULUAN}

Disadari atau tidak, proses pendidikan di sekolah sekarang porsinya masih lebih pada aspek kognitif atau transfer of knowledge saja. Salah satu hal yang kadang dihadapi guru dalam pembelajaran adalah kurangnya minat dan motivasi peserta didik untuk belajar di kelas. Kadangkala peserta didik mempraktikkan "5D" yaitu Datang, Duduk, Dengar, Diam, dan bahkan mungkin Dengkur. Berdasarkan observasi, kondisi riil terlihat bahwa proses pembelajaran. Peserta didik kadangkala merasa "terpaksa" datang dan menghabiskan waktunya di kelas. Apalagi apabila guru masih terbiasa untuk menjadikan peserta didiknya pendengar yang baik karena guru masih yakin bahwa satu-satunya cara untuk mengajar dengan cepat adalah dengan menggunakan metode ceramah.

Berdasarkan pengalaman menjadi asesor pada saat melakukan akreditasi, banyak hal yang diperoleh,selain informasi tentang hal-hal pokok meliputi Standar Isi, Standar proses, Standar Kompetensi Lulusan, Standar pengelolaan, Standar pembiayaan, Standar penilaian yang disesuaikan dengan kondisi riil sekolah tersebut, yang penulis garis bawahi adalah standar penilaian. Pada standar penilaian diharapkan guru dapat mengembangkan instrumen dan pedoman penilaian sesuai dengan bentuk dan teknik penilaian. Tetapi fakta dilapangan berbicara lain, ditemukan bahwa instrumen penilaian hanya berada di ranah kognitif saja, sementara instrumen penilaian pada ranah afektif, lebih-lebih lagi instrumen penilaian ranah psikomotorik jarang ditemukan bahkan hal yang lebih menyedihkan adalah guru tidak pernah melakukan melakukan penilaian pada kedua ranah ini.

Padahal jika dilihat secara umum, proses pendidikan menuju pada tiga hal pokok yang harus mampu dicapai peserta didik, yaitu Afektif, Kognitif dan Psikomotorik. Afektif berkaitan dengan sikap, moral, etika, akhlak, dan manajemen emosi. Kognitif berkaitan dengan aspek pemikiran, transfer ilmu, logika, dan analisis. Sedangkan Psikomotorik berkaitan dengan praktik atau aplikasi apa yang sudah diperolehnya melalui jalur kognitif.

Pengembangan dan penyempurnaan kurikulum mata pelajaran pada sekolah merupakan bagian dari upaya peningkatan mutu pendidikan sekolah. Indikator keberhasilan dari pembaharuan kurikulum tersebut ditunjukkan dengan adanya perubahan pada pola kegiatan belajar mengajar, memilih media pendidikan, dan 
menentukan pola penilaian yang menentukan hasil pendidikan di sekolah.

Pembaharuan kurikulum akan lebih bermakna bila diikuti oleh perubahanperubahan praktek pembelajaran di kelas yang dengan sendirinya akan mengubah praktek-praktek penilaian. Selama ini praktek penilaian di kelas masih menekankan aspek kognitif. Penilaian tersebut lebih diarahkan pada penguasaan bahan yang diujikan dalam bentuk tes obyektif dan kurang menggunakan cara dan alat evaluasi yang lebih bervariasi. Untuk itu sistem penilaian perlu dirubah. Ke depan, dalam pembelajaran guru mutlak perlu menerapkan instrument pada ketiga domain pembelajaran.

Dalam pembelajaran, semua mata pelajaran, ranah yang dinilai perlu diperluas termasuk sikap dan keterampilan. Penilaian perlu menggunakan alat dan cara yang bervariasi dalam pengumpulan informasi untuk menilai kemajuan hasil belajar siswa. Dengan demikian, penilaian berbasis kelas dilakukan untuk memberikan keseimbangan pada ketiga ranah kognitif, afektif, dan psikomotorik dengan menggunakan berbagai bentuk model penilaian resmi maupun tidak resmi secara berkesinambungan. Keseimbangan instrumen penilaian pada ketiga domain pembelajaran diharapkan bermanfaat untuk memperoleh keutuhan gambaran (profil) prestasi dan kemajuan belajar siswa sekolah.

\section{PEMBAHASAN}

Penilaian otentik perlu dilakukan terhadap keseluruhan kompetensi yang telah dipelajari siswa melalui kegiatan pembelajaran. Ditinjau dari dimensi kompetensi yang ingin dicapai, ranah yang perlu dinilai meliputi ranah kognitif, psikomotor, dan afektif.

\section{Aspek Kognitif}

Ranah kognitif adalah ranah yang mencakup kegiatan mental (otak). Menurut Bloom, segala upaya yang menyangkut aktivitas otak adalah termasuk dalam ranah kognitif. Ranah kognitif berhubungan dengan kemampuan berfikir, termasuk di dalamnya kemampuan menghafal, memahami, mengaplikasi, menganalisis, mensintesis, dan kemampuan mengevaluasi. Dalam ranah kognitif itu terdapat enam aspek atau jenjang proses berfikir, mulai dari jenjang terendah sampai dengan jenjang yang paling tinggi. Keenam jenjang atau aspek yang dimaksud adalah:

a. Pengetahuan/hafalan/ingatan (knowledge) adalah kemampuan seseorang untuk mengingat-ingat 
kembali (recall) atau mengenali kembali tentang nama, istilah, ide, rumus-rumus, dan sebagainya, tanpa mengharapkan kemampuan untuk menggunkannya. Pengetahuan atau ingatan adalah merupakan proses berfikir yang paling rendah. Salah satu contoh hasil belajar kognitif pada jenjang pengetahuan adalah dapat menghafal rukun Islam dan menuliskannya dengan berurutan, sebagai salah satu materi pelajaran kedisiplinan yang diberikan oleh guru Pendidikan Agama Islam di sekolah.

b. Pemahaman (comprehension) adalah kemampuan seseorang untuk mengerti atau memahami sesuatu setelah sesuatu itu diketahui dan diingat. Dengan kata lain, memahami adalah mengetahui tentang sesuatu dan dapat melihatnya dari berbagai segi. Seorang peserta didik dikatakan memahami sesuatu apabila ia dapat memberikan penjelasan atau memberi uraian yang lebih rinci tentang hal itu dengan menggunakan kata-katanya sendiri. Pemahaman merupakan jenjang kemampuan berfikir yang setingkat lebih tinggi dari ingatan atau hafalan.Salah satu contoh hasil belajar ranah kognitif pada jenjang pemahaman ini misalnya: peserta didik dapat menjawab pertanyaan guru Bahasa Indonesia mengenai unsur-unsur intrinsik cerita pendek dengan memberi contoh menggunakan kalimat sendiri.

c. Penerapan (application) adalah kesanggupan seseorang untuk menerapkan atau menggunakan ideide umum, tata cara ataupun metodemetode, prinsip-prinsip, rumusrumus, teori-teori dan sebagainya, dalam situasi yang baru dan kongkret. Penerapan ini adalah merupakan proses berfikir setingkat lebih tinggi dari pemahaman. Salah satu contoh hasil belajar kognitif jenjang penerapan misalnya: Peserta didik mampu memikirkan tentang penerapan konsep kedisiplinan yang diajarkan Islam dalam kehidupan sehari-hari baik dilingkungan keluarga, sekolah, maupun masyarakat.

d. Analisis (analysis) adalah kemampuan seseorang untuk merinci atau menguraikan suatu bahan atau keadaan menurut bagian-bagian yang lebih kecil dan mampu memahami hubungan di antara bagian-bagian atau faktor-faktor yang satu dengan 
faktor-faktor lainnya. Jenjang analisis adalah setingkat lebih tinggi dari jenjang aplikasi. Contoh: Peserta didik dapat merenung dan memikirkan dengan baik tentang wujud nyata dari kedisiplinan seorang siswa di rumah, di sekolah, dan dalam kehidupan sehari-hari di tengah-tengah masyarakat, sebagai bagian dari ajaran Islam.

e. Sintesis (syntesis) adalah kemampuan berfikir yang merupakan kebalikan dari proses berfikir analisis. Sisntesis merupakan suatu proses yang memadukan bagianbagian atau unsur-unsur secara logis, sehingga menjelma menjadi suatu pola yang terstruktur atau membentuk pola baru. Jenjang sintesis kedudukannya setingkat lebih tinggi dari jenjang analisis. Salah satu hasil belajar kognitif dari jenjang sintesis ini adalah: peserta didik dapat menulis karangan tentang pentingnya kedisiplinan sebagiamana telah diajarkan oleh islam.

f. Penilaian/penghargaan/evaluasi (evaluation) adalah merupakan jenjang berpikir paling tinggi dalam ranah kognitif dalam taksonomi Bloom. Penilian/evaluasi di sini merupakan kemampuan seseorang untuk membuat pertimbangan terhadap suatu kondisi, nilai atau ide, misalkan jika seseorang dihadapkan pada beberapa pilihan maka ia akan mampu memilih satu pilihan yang terbaik sesuai dengan patokanpatokan atau kriteria yang ada. Salah satu contoh hasil belajar kognitif jenjang evaluasi adalah: peserta didik mampu menimbang-nimbang tentang manfaat yang dapat dipetik oleh seseorang yang berlaku disiplin dan dapat menunjukkan akibat-akibat negatif yang akan menimpa seseorang yang bersifat malas atau tidak disiplin, sehingga pada akhirnya sampai pada kesimpulan penilaian.

Keenam jenjang berpikir ranah kognitif bersifat kontinum dan overlap (tumpang tindih), dimana ranah yang lebih tinggi meliputi semua ranah yang ada dibawahnya.

\section{Aspek Afektif}

Ranah afektif adalah ranah yang berkaitan dengan sikap dan nilai. Ranah afektif mencakup watak perilaku seperti perasaan, minat, sikap, emosi, dan nilai. Beberapa pakar mengatakan bahwa sikap seseorang dapat diramalkan perubahannya 
bila seseorang telah memiliki kekuasaan kognitif tingkat tinggi. Ciri-ciri hasil belajar afektif akan tampak pada peserta didik dalam berbagai tingkah laku. Ranah afektif menjadi lebih rinci lagi ke dalam lima jenjang, yaitu: (1) Receiving

Responding (3) Valuing (4) Organization (5) characterization by evalue or calue complex.

a. Receiving atau attending (menerima atau memperhatikan), adalah kepekaan seseorang dalam menerima rangsangan (stimulus) dari luar yang datang kepada dirinya dalam bentuk masalah, situasi, gejala dan lain-lain. Termasuk dalam jenjang ini misalnya adalah: kesadaran dan keinginan untuk menerima stimulus, mengontrol dan menyeleksi gejalagejala atau rangsangan yang datang dari luar. Receiving atau attenting juga sering diberi pengertian sebagai kemauan untuk memperhatikan suatu kegiatan atau suatu objek. Pada jenjang ini peserta didik dibina agar mereka bersedia menerima nilai atau nilai-nilai yang diajarkan kepada mereka, dan mereka mau menggabungkan diri ke dalam nilai itu atau mengidentifikasikan diri dengan nilai itu. Contah hasil belajar afektif jenjang receiving, misalnya: peserta didik bahwa disiplin wajib di tegakkan, sifat malas dan tidak di siplin harus disingkirkan jauh-jauh.

\section{b. Responding}

(menanggapi)

mengandung arti "adanya partisipasi aktif'. Jadi kemampuan menanggapi adalah kemampuan yang dimiliki oleh seseorang untuk mengikutsertakan dirinya secara aktif dalam fenomena tertentu dan membuat reaksi terhadapnya salah satu cara. Jenjang ini lebih tinggi daripada jenjang receiving.

c. Valuing (menilai/menghargai). Menilai atau menghargai artinya memberikan nilai atau memberikan penghargaan terhadap suatu kegiatan atau obyek, sehingga apabila kegiatan itu tidak dikerjakan, dirasakan akan membawa kerugian atau penyesalan. Valuing adalah merupakan tingkat afektif yang lebih tinggi lagi daripada receiving dan responding. Dalam kaitan dengan proses belajar mengajar, peserta didik tidak hanya mau menerima nilai yang diajarkan tetapi mereka telah berkemampuan untuk menilai konsep atau fenomena, yaitu baik atau buruk. Bila suatu ajaran yang telah mampu mereka nilai dan mampu untuk mengatakan "itu 
adalah baik", maka ini berarti bahwa peserta didik telah menjalani proses penilaian. Nilai itu mulai dicamkan (internalized) dalam dirinya. Dengan demikian nilai tersebut telah stabil dalam peserta didik. Contoh hasil belajar efektif jenjang valuing adalah tumbuhnya kemampuan yang kuat pada diri peseta didik untuk berlaku disiplin, baik disekolah, dirumah maupun di tengah-tengah kehidupan masyarakat.

d. Organization (mengatur atau mengorganisasikan), artinya mempertemukan perbedaan nilai sehingga terbentuk nilai baru yang universal, yang membawa pada perbaikan umum. Mengatur atau mengorganisasikan merupakan pengembangan dari nilai kedalam satu sistem organisasi, termasuk di dalamnya hubungan satu nilai denagan nilai lain. Pemantapan dan perioritas nilai yang telah dimilikinya. Contoh nilai efektif jenjang organization adalah peserta didik mendukung penegakan disiplin nasional yang telah dicanangkan oleh bapak presiden Soeharto pada peringatan hari kemerdekaan nasional tahun 1995. e. Characterization by evalue or calue complex (karakterisasi dengan suatu nilai atau komplek nilai), yakni keterpaduan semua sistem nilai yang telah dimiliki oleh seseorang, yang mempengaruhi pola kepribadian dan tingkah lakunya. Proses internalisasi nilai telah menempati tempat tertinggi dalam suatu hirarki nilai. Nilai itu telah tertanam secara konsisten pada sistemnya dan telah mempengaruhi emosinya. Ini adalah merupakan tingkat efektif tertinggi, karena sikap batin peserta didik telah benar-benar bijaksana. Ia telah memiliki phyloshopphy of life yang mapan. Jadi pada jenjang ini peserta didik telah memiliki sistem nilai yang telah mengontrol tingkah lakunya untuk suatu waktu yang lama, sehingga membentu karakteristik "pola hidup" tingkah lakunya menetap, konsisten dan dapat diramalkan. Contoh hasil belajar afektif pada jenjang ini adalah siswa telah memiliki kebulatan sikap wujudnya peserta didik menjadikan perintah Allah SWT yang tertera di Al-Quran menyangkut disiplinan, baik kedisiplinan sekolah, di rumah 
maupun di tengah-tengah kehidupan masyarakat.

\section{Ranah Psikomotor}

Ranah psikomotor merupakan ranah yang berkaitan dengan keterampilan (skill) atau kemampuan bertindak setelah seseorang menerima pengalaman belajar tertentu. Ranah psikomotor adalah ranah yang berhubungan dengan aktivitas fisik, misalnya lari, melompat, melukis, menari, dan sebagainya. Hasil belajar ranah psikomotor dikemukakan oleh Simpson (1956) yang menyatakan bahwa hasil belajar psikomotor ini tampak dalam bentuk keterampilan (skill) dan kemampuan bertindak individu. Hasil belajar psikomotor ini sebenarnya merupakan kelanjutan dari hasil belajar kognitif (memahami sesuatu) dan hasil belajar afektif (yang baru tampak dalam bentuk kecenderungan-kecenderungan berperilaku). Hasil belajar kognitif dan hasil belajar afektif akan menjadi hasil belajar psikomotor apabila peserta didik telah menunjukkan perilaku atau perbuatan tertentu sesuai dengan makna yang terkandung dalam ranah kognitif dan ranah afektif. Ranah psikomotor menjadi lebih rinci lagi ke dalam enam jenjang, yaitu: a. Gerakan Refleks adalah basis semua perilaku bergerak, respons terhadap stimulus tanpa sadar. Misalnya : melompat, menunduk, berjalan, menggerakkan leher dan kepala, menggenggam, memegang.

b. Gerakan dasar (basic fundamental movements) gerakan ini muncul tanpa latihan tapi dapat diperhalus melalui praktik gerakan ini terpola dan dapat ditebak seperti gerakan tak berpindah: bergoyang, membungkuk, merentang, mendorong, menarik, memeluk, berputar. Gerakan berpindah: merangkak, maju perlahan-lahan, muluncur, berjalan, berlari, meloncat-loncat, berputar mengitari, memanjat. Gerakan manipulasi: menyusun balok/blok, menggunting, menggambar dengan krayon, memegang dan melepas objek, blok atau mainan. Keterampilan gerak tangan dan jarijari : memainkan bola, menggambar.

c. Gerakan persepsi (Perceptual obilities) gerakan sudah lebih meningkat karena dibantu kemampuan perseptual. Seperti menangkap bola dan mendrible bola. Gerakan sambil menjaga keseimbangan memilih satu objek kecil dari sekelompok objek yang 
ukurannya bervariasi, menulis alfabet, dan membedakan suara berbagai binatang.

d. Gerakan kemampuan fisik (Psycal abilities) gerak lebih efisien, berkembang melalui kematangan dan belajar seperti menggerakkan otot/sekelompok otot selama waktu tertentu, berlari jauh, mengangkat beban,dan menarik-mendorong.

e. Gerakan terampil (Skilled movements) dapat mengontrol berbagai tingkat gerak-terampil, tangkas, cekatan melakukan gerakan yang sulit dan rumit (kompleks) seperti melakukan gerakan terampil berbagai cabang olahraga, menari, berdansa, membuat kerajinan tangan, menggergaji, mengetik, bermain piano, dan memanah.

f. Gerakan indah dan kreatif (Nondiscursive communication) mengkomunikasikan perasaan melalui gerakan seperti melakukan senam tingkat tinggi dan bermain drama (acting).

Penilaian dalam pembelajaran dapat membantu peserta didik untuk memperkuat motivasi belajarnya, memperbesar daya ingat dan transfer belajarnya, memperbesar pemahaman peserta didik terhadap keberadaan dirinya dan memberikan umpan balik tentang efektivitas pembelajaran. Untuk itu, penilaian tersebut membutuhkan analisa dan batasan pengataman serta ukuran bagi pendidik dalam mengukur sejauhmana pemahaman, keahlian dan sikap peserta didik pada saat proses dan setelah menyelesaikan suatu pembelajaran. Seyogyanya bagi pendidik harus mengerti dan memahami suatu bentuk analisa dan penilaian hasil belajar pada peserta didik, yang terdiri pada penilaian pada ranah kognitif (pengetahuan), pada ranah afektif (sikap) dan ranah psikomotor (keahlian/implementasi). Penilaian hasil belajar ini tentu akan menjadi beragam pada masing-masing peserta didik karena dipengaruhi oleh latar belakang peserta didik, maka keahlian pendidik juga menjadi faktor penting dalam memberikan penilaian pada hasil belajarnya.

Keseimbangan tiga ranah-penilaian yang dilakukan oleh pendidik harus memuat keseimbangan tiga ranah; kognitif, psikomotorik, dan afektif. Karena itu perlu diperhatikan hal-hal sebagai berikut;

a).Penilaian aspek kognitif dilakukan setelah siswa mempelajari satu kompetensi dasar yang harus dicapai, b).Penilaian aspek afektif dilakukan selama berlangsungnya kegiatan belajar mengajar, baik di dalam maupun di luar kelas, c). Penilaian aspek 
psikomotorik dilakukan selama

berlangsungnya proses kegiatan belajar mengajar.

Nampak jelas deskriptif pada ketiga ranah tersebut, sehingga cukup terinci dan terarah apabila guru akan membuat instrumen penilaian pada ketiga ranah tersebut serta melakukan implementasi penilaiannya. Hanya saja, sangat disayangkan kreatifitas guru dalam mengembangkan instrumen penilaian pada ketiga ranah tersebut masih sangat lemah. Alasan beberapa guru tidak melakukan keseimbangan penilaian pada ketiga ranah tersebut, akan menghabiskan waktu yang relatif lebih lama. Keadaaan semacam ini merupakan salah satu penyebab enggannya gurun untuk melakukan kegiatan pembelajaran yang memfokuskan pada penilaian proses dan penilaian hasil. Kondisi ini sesuai dengan apa yang dikemukan oleh Baedhowi bahwa tidak mudah untuk melaksanakan penilaian yang mengacu pada tiga ranah hasil belajar, yaitu kognitif, afektif dan psikomotorik karena adanya berbagai faktor, antara lain : (1) Komitmen yang masih rendah, (2) Kemampuan dan pengetahuan yang kurang memadai, (3) Keterbatasan sarana dan daya penunjang, (4) Adanya political will baik dari dari pemerintah pusat, pemerintah daerah maupun sekolah, (5) Diseminasi informasi yang kurang efektif.

\section{SIMPULAN}

Dalam banyak kasus, penilaian tidak dilakukan berdasarkan standar yang akurat, hanya berdasarkan keyakinan, pengetahuan dan pengalaman guru terhadap kondisi siswa. Banyak guru merasa tidak cukup siap untuk melakukan penilaian pada tiga ranah pembelajaran ini secara komprehensif. Banyak alasan yang dikemukan oleh guru terkait pelaksanaan penilaian pada ranah kognitif, afektif dan psikomotorik, tetapi guru yang sadar akan tugas dan tanggungjawabnya dalam melakukan proses dan hasil belajar seyogyanya melakukan apa yang seharusnya dilakukan. Sangat disadari bahwa tidak mudah untuk melakukan keseimbangan instrumen penilaian pada ketiga domain pembelajaran, apalagi jika dikaitkan dengan penerapannya di kelas. Tetapi bukankah, menjadi suatu hal kepuasan guru apabila bisa berkarya sesederhana apapun dan sekecil apapun. Walaupun guru merupakan salah satu komponen dari sistem pendidikan tapi ditangan gurulah, kesuksesan pembelajaran akan tercapai. 


\section{REFRESENSI}

Anderson, Lorin W. and Krathwohl, David

R. A. Taxonomy for learning, teaching, and Assessing: A Revisi

of Bloom"s Taxonomy of Educational Objectives. A Bridged edition. Addison Wesley Longman, Inc. 2001.

Burke, Kay. How to Assess Authentic Learning. Fifth Edition. New Delhi. Mathura Road, 2009.

Driscoll, Marcy P. Psychology of Learning for Instruction, Second Edition. Massachusetts: Pearson Educational Company. 2000.

Gagne, Robet $\mathrm{M}$ et al., Principles of Instructional Design. Colonia Polanco: Thomson Learning, Inc. 2005.

Gredler, Margaret E. Bell. Learning and intruction Theory into Practice, Pearson Education, Inc, 2009

Meyer," Authentic Assessment". http://.learner.org/channel/workshop /socialstudies/pdf/session7/7.perform ance assessment. Pdf (diunduh tanggal 20 April 2010).

Smaldino, Sharon E., Deborah L Lowther, James D. Russel. Instructional Technology and media for
Learning. New Jersey: Pearson education, Inc, 2007. 